\title{
Up-regulation of adrenomedullin gene expression in the regenerating rat adrenal cortex
}

\author{
PIERA REBUFFAT ${ }^{1}$, CARLO MACCHI $^{1}$, LUDWIK K. MALENDOWICZ $^{2}$ and GASTONE G. NUSSDORFER ${ }^{1}$ \\ ${ }^{1}$ Department of Human Anatomy and Physiology, University of Padua, I-35121 Padua, Italy; \\ ${ }^{2}$ Department of Histology and Embryology, Poznan School of Medicine, PL-60781 Poznan, Poland
}

Received June 5, 2007; Accepted July 12, 2007

\begin{abstract}
Adrenomedullin (AM) is an endogenous regulatory peptide that exerts growth-promoting action in several normal and neoplastic tissues, and we investigated whether its gene expression changes during rat adrenal regeneration after enucleation and contra-lateral adrenalectomy. Regenerating adrenals were collected at day 0 (just after enucleation; control rats), 1, 3, 7, 14 and 28 after surgery. The immunocytochemical assay of PCNA (proliferating cell nuclear antigen) index confirmed that the early stages of regeneration can be divided into an initial differentiation period (from day 0 to day 3 ) and a subsequent high proliferative period (days 5 and 7) followed by a decrease in the proliferation activity. Real time-polymerase chain reaction (PCR) demonstrated that AM mRNA expression underwent a marked rise at day 1 of regeneration, attained a maximum level at days 3 and 5, and then declined from day 7 , returning to the control value at days 14 and 28. Western blotting showed that AM protein expression was moderately elevated at day 1, was maximal between days 3 and 7, and then decreased at days 14 and 28, although remaining significant over the control value. Taken together, our findings indicate that the increase in the AM gene transcription and translation may be considered one of the early events in the enucleation-induced activation of local adrenocortical stem cells, conceivably favoring both the differentiation and proliferation stages of regeneration. The mechanism underlying this adrenocortical stem cell response does not seem to involve ACTH, because real time-PCR demonstrated that it also occurred in animals whose contralateral adrenal glands were spared, and consequently the level of circulating ACTH was in the normal range. It remains to be investigated whether the enucleation-induced relative hypoxia, ensuing from disruption of the vascular bed,
\end{abstract}

Correspondence to: Professor G.G. Nussdorfer, Department of Human Anatomy and Physiology, Section of Anatomy, Via Gabelli 65, I-35121 Padua, Italy

E-mail: gastone.nusdorfer@unipd.it

Key words: adrenal regeneration, adrenocortical stem cells, adrenomedullin, rat and the local release of inflammatory cytokines may be involved in the up-regulation of AM gene expression in regenerating adrenal glands.

\section{Introduction}

The mammalian adrenal cortex is composed of three concentric functionally distinct zones, the subcapsular mineralocorticoid-secreting zona glomerulosa $(\mathrm{ZG})$, the middle glucocorticoid-secreting zona fasciculata (ZF), and the inner juxtamedullary zona reticularis (ZR), that produces glucocorticoids and androgens $(1,2)$. Most mitoses occur in the $Z G$, and most apoptotic cell death in the ZR, which has led to the 'cell migration' theory. According to this theory, new cells arise from stem cells located in the $\mathrm{ZG}$, migrate into the $\mathrm{ZF}$ and then reach $Z R$, where exhausted aged cells die (1). An alternative view localizes adrenocortical stem cells in an undifferentiated zona intermedia between ZG and ZF (3). Under normal conditions, the renewal rate of adrenocortical cells is very low, so that it is conceivable that most stem cells are dormant. Many physiological agonists of adrenal cortex, such as ACTH and angiotensin-II, are able to stimulate adrenocortical growth by enhancing cell division in the ZG $(1,3,4)$.

A useful experimental model of rapid adrenocortical growth, and of subsequent strong activation of local stem cells, is regeneration after enucleation. Following enucleation with the removal of the inner cortex and medulla, remnant parenchymal cells adherent to the gland connective capsule proliferate and restore structural adrenocortical zonation within 4-6 weeks. Optimal regeneration requires contralateral adrenalectomy because glucocorticoid secretion from the remaining intact adrenal prevents the increased ACTH secretion, which is essential in driving regeneration $(1,4-8)$. Apart from ACTH, several other regulatory peptides have been reported to favor rat adrenocortical regeneration, and among them adrenomedullin (AM) appears to play a major role (9).

$\mathrm{AM}$ is a multi-functional regulatory peptide, originally isolated from human pheochromocytomas, that exerts potent vasorelaxant and hypotensive effects. AM and its receptors are widely expressed in tissues and organs, where AM controls specific and basic functions probably acting in an autocrine-paracrine manner (10-12). Evidence has been provided that AM plays a relevant role in the regulation of 
mammalian adrenal cortex physiology. It inhibits $\mathrm{Ca}^{2+}-$ dependent agonist-stimulated aldosterone secretion (13) and enhances proliferation of ZG cells both in vivo (14) and in vitro (15-18); $\mathrm{AM}$ and its receptor genes being exclusively expressed in the ZG (16-18). The adrenal growth model during regeneration after enucleation resembles that occurring in embryogenesis (4), where the growth-promoting action of AM is thought to play a relevant role (19). Accordingly, Albertin et al (9) showed overexpression of AM mRNA in the regenerating adrenals, as compared to sham-enucleated glands.

In the latter study (9) neither the expression of AM as protein nor the early phases (first 3 days) of regeneration were examined. Moreover, sham-enucleated adrenal tissue is not a reliable control because it leads to the over-estimation of AM mRNA up-regulation in regenerating adrenals, as the AM gene is expressed only in the ZG. In fact, AM mRNA content is conceivably under-estimated in the entire adrenal tissue with respect to the regenerating tissue, which is exclusively derived from ZG. Therefore, we investigated the expression of AM as mRNA and protein at the early, middle and late stages of adrenal regeneration using regenerating tissue at time 0 (immediately after enucleation) as a control.

\section{Materials and methods}

Animals and experimental design. Adult male SpragueDawley rats, weighing 200-220 g, were obtained from Charles-River (Como, Italy). Animals were kept under a 12:12 $\mathrm{h}$ light-dark cycle at $23^{\circ} \mathrm{C}$ and maintained on a standard diet and tap water ad libitum until surgery. The experimental protocol was approved by the local Ethics Committee for Animal Studies, and experiments were carried out according to the Italian Law on the protection of laboratory animals. Under ether anesthesia, the left adrenal gland of 63 rats was enucleated, and the right adrenal gland was removed. Surgery was carried out by the dorsal approach without opening the peritoneum (9). Enucleation consisted of an incision to the adrenal capsule and extrusion and complete removal of the inner cortex and medulla; only ZG cells adherent to the capsule remained in situ. Rats were given an intramuscular injection of amplital (30 mg/100g body weight) immediately after surgery, housed in individual sterile cages, and maintained on a standard diet and $0.9 \% \mathrm{NaCl}$ to drink. Animals were decapitated at day 0 (60 min after enucleation; control group), 1, 3, 5, 7, 14 and 28 after surgery ( 9 rats for each time point), and their regenerating adrenals were promptly removed. Three regenerating adrenals for each group of rats at each time point were fixed in Bouin's solution for $24 \mathrm{~h}$, embedded in paraffin and sectioned at a $6-\mu \mathrm{m}$ thickness for immunocytochemistry. Other specimens were frozen and stored at $-80^{\circ} \mathrm{C}$ for reverse transcription (RT)polymerase chain reaction (PCR) and Western blot analysis (3 regenerating adrenals for each time point for each technique).

Nine rats underwent left adrenal enucleation as described above, but the right gland was not excised. They were decapitated at day 0,3 and 5 after surgery (three rats for each time point), and their regenerating adrenals were removed and used for RT-PCR.

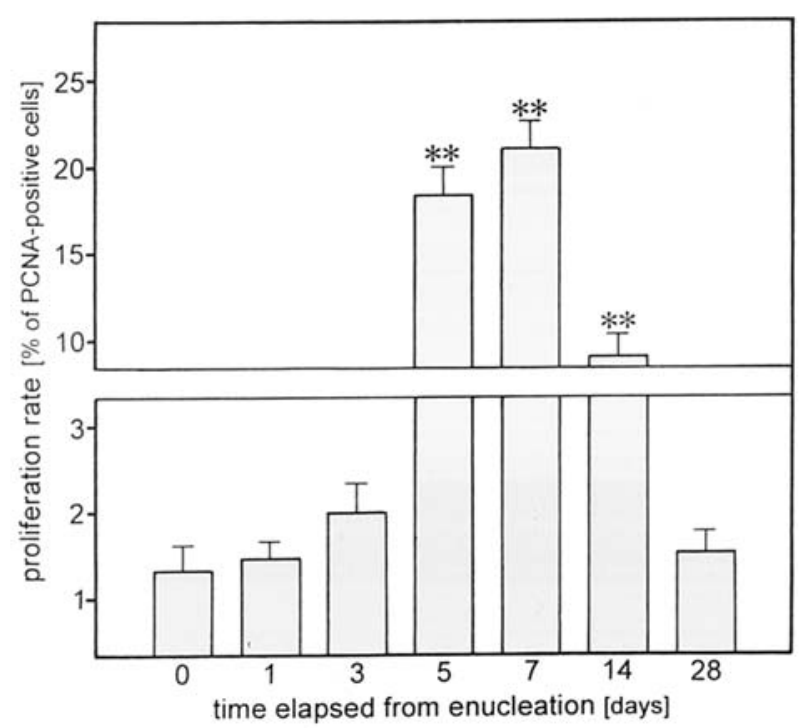

Figure 1. Proliferation rate of regenerating rat adrenal cortex in relation to the time elapsed from enucleation and contra-lateral adrenalectomy. Bars are the means $\pm \operatorname{SEM}(\mathrm{n}=3) .{ }^{* *} \mathrm{P}<0.01$ compared to the controls (time 0$)$.

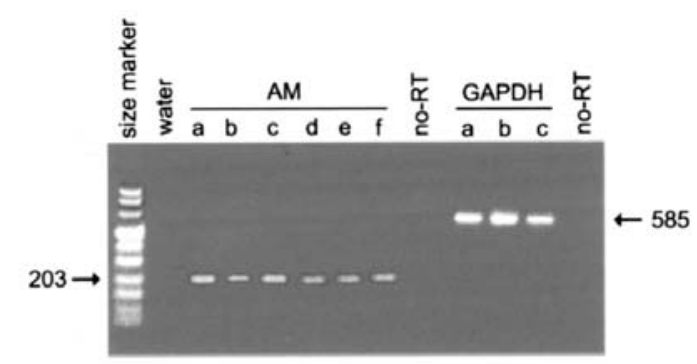

Figure 2. Ethidium bromide-stained $2 \%$ agarose gel showing cDNA amplified with rat AM and GAPDH-specific primers from RNA of regenerating adrenal cortex of control rats which underwent enucleation with $(\mathrm{a}, \mathrm{b}, \mathrm{c})$ and without contra-lateral adrenalectomy (d,e,f). Primer sequences included AM sense-9-5', 5'-GCAGAACAACTCCAGCCTTT-3' and AM antisense-211-3', 5'-GCGAACCCAATAACATCAGG-3' (203 bp); GAPDH sense-181-5', 5'-CCCTTCATTGACCTCAACTA-3' and GAPDH antisense-765-3', 5'-GCCAGTGAGCTTCCCGTTCA-3' (585 bp). The PCR program was 35 cycles at $95^{\circ} \mathrm{C}$ for $60 \mathrm{sec}, 57^{\circ} \mathrm{C}$ for $45 \mathrm{sec}$ and $72^{\circ} \mathrm{C}$ for $90 \mathrm{sec}$. The first lane was loaded with $200 \mathrm{ng}$ of Marker VIII (Boehringer, Mannheim, Germany). No amplification of PCR mixture without prior RT of RNA is shown as the negative control.

Proliferating cell nuclear antigen (PCNA) immunostaining. The PCNA immunostaining technique was used to estimate the number of regenerating adrenal cells entering the $S$ phase of their cycle (20). PCNA-positive cells were identified using the LSAB2 kit purchased from Dako (Glostrup, Denmark). Peroxidase-labeled antibodies were detected with Sigma Fast 3',3'-diaminobenzidine $0.7 \mathrm{mg}$ tablets (Sigma-Aldrich Corp., St. Louis, MO). Negative controls were carried out by omitting the primary antibody. Nuclei were counterstained with hematoxylin, and the PCNA index (\% of PCNA-positive cells) was calculated at $\mathrm{x} 400$ by counting 2,000 cells in each regenerating adrenal tissue.

$R T-P C R$. Total RNA was extracted from the regenerating adrenal cortexes and reverse transcribed to cDNA (21-24). 


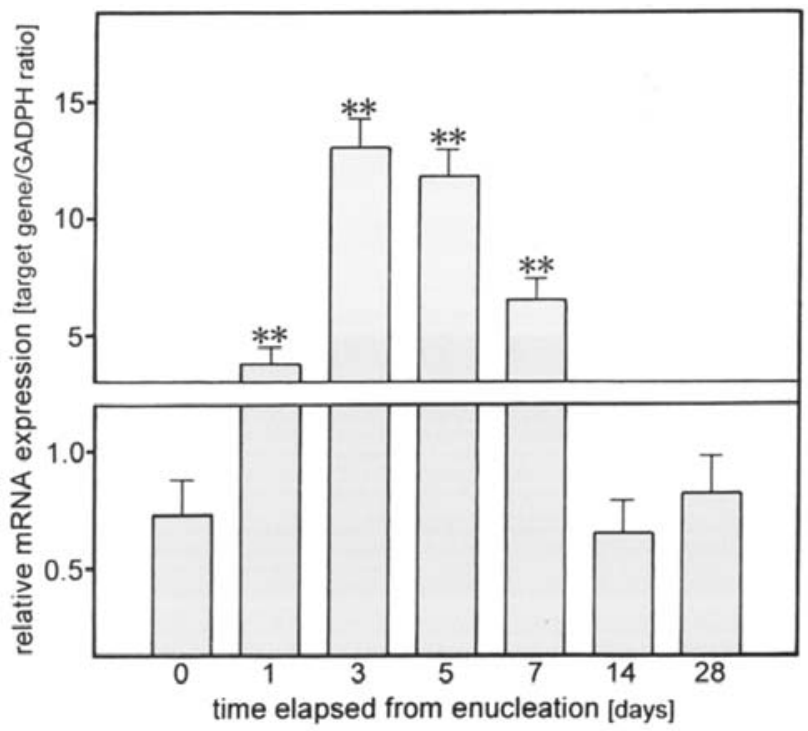

Figure 3. Semi-quantitative real time-PCR assay of AM mRNA expression in the regenerating rat adrenal cortex in relation to the time elapsed from enucleation and contra-lateral adrenalectomy. Bars are the means \pm SEM $(\mathrm{n}=3) .{ }^{* *} \mathrm{P}<0.01$ compared to the controls (time 0$)$.

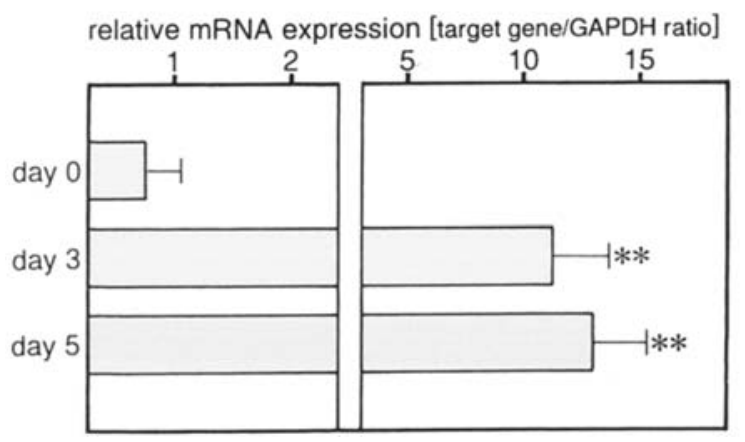

Figure 4. Semi-quantitative real time-PCR assay of AM mRNA expression in the regenerating rat adrenal cortex in relation to the time elapsed from enucleation without contra-lateral adrenalectomy. Bars are the means \pm SEM ( $n=3) .{ }^{*} \mathrm{P}<0.05$ and ${ }^{* *} \mathrm{P}<0.01$ compared to the controls (time 0 ).

Conventional PCR was carried out as previously described $(9,25,26)$ using the primers indicated in the legend of Fig. 2. To rule out the possibility of amplifying genomic DNA, one PCR was performed without prior RT of the RNA. Detection of the PCR amplification product was carried out by size fractionation on $2 \%$ agarose gel electrophoresis. The specificity of the PCR was verified by sequencing analysis (27). Semi-quantitative real time-PCR was performed as previously detailed (28-31) in a Bio-Rad I-Cycler iQ Detection System (Bio-Rad Laboratories, Milan, Italy). Briefly, reactions were carried out in $25 \mu 1$ of final volume solution containing 800-nM-specific primers (Fig. 2 legend), $12.5 \mu 1$ iQ Sybr-Green Supermix (Bio-Rad Laboratories) and $2 \mu \mathrm{l}$ of RT-reaction solution. The PCR program included a denaturation step at $95^{\circ} \mathrm{C}$ for $3 \mathrm{~min}, 35$ cycles of two amplification steps $\left(95^{\circ} \mathrm{C}\right.$ for $15 \mathrm{sec}$ and annealing at $60^{\circ} \mathrm{C}$ for $30 \mathrm{sec}$ ), and melting curve at $60-90^{\circ} \mathrm{C}$ with a heating rate of $0.5^{\circ} \mathrm{C} / 10 \mathrm{sec}$. The specificity of amplification was tested at

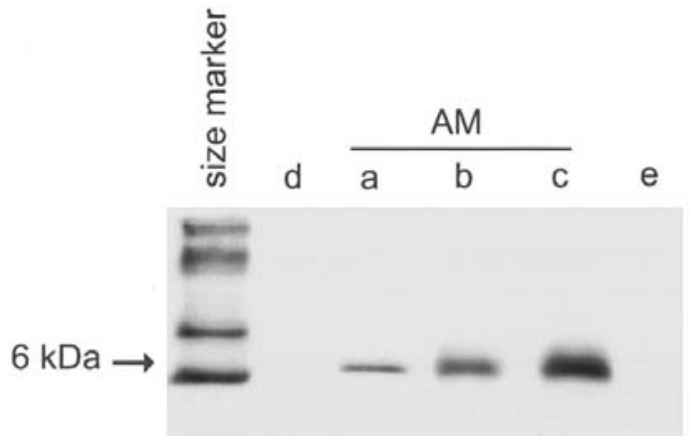

Figure 5. Western blot analysis of AM in exemplary protein extracts from the regenerating rat adrenal cortex at days 0 (a), 1 (b) and 5 (c) from enucleation and contra-lateral adrenalectomy. AM protein is recognized as a single band of $\sim 6 \mathrm{kDa}$, and the specificity of detection is demonstrated by the absence of immunodetection when the antibody was preabsorbed with $10^{-7}$ M AM. Molecular mass standards are shown in lane 1.

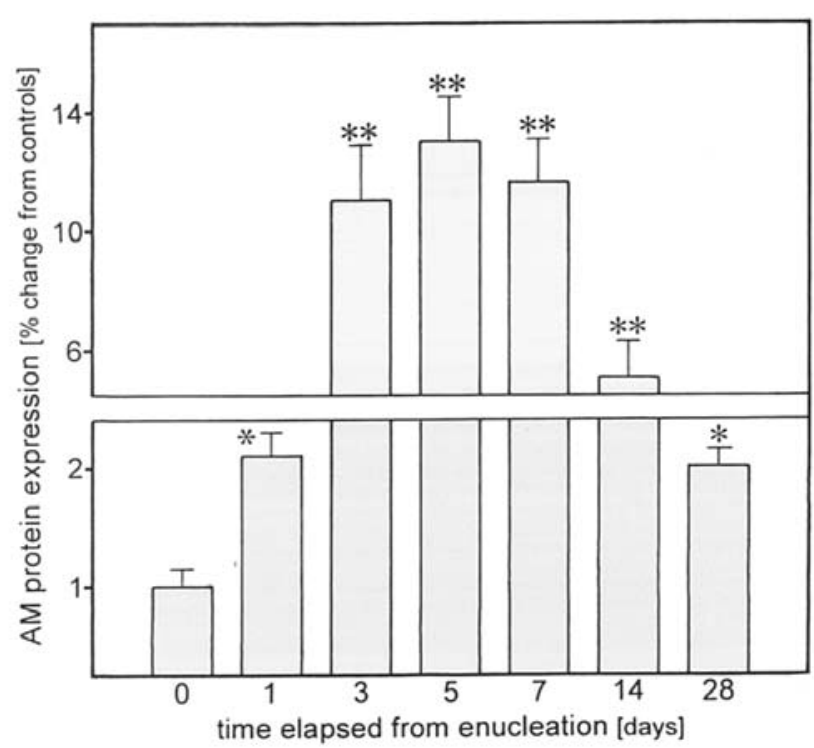

Figure 6. Quantitative Western blot analysis of AM protein expression in the regenerating rat adrenal cortex in relation to the time elapsed from enucleation and contra-lateral adrenalectomy. Bars are the means \pm SEM $(\mathrm{n}=3) .{ }^{*} \mathrm{P}<0.05$ and ${ }^{* *} \mathrm{P}<0.01$ compared to the controls (time 0$)$.

the end of each run by real time melting analysis using the ICycler iQ software 3.0. All samples were amplified in duplicate, and glyceraldehyde-3-phosphate dehydrogenase (GAPDH) was used as a housekeeping gene; its mRNA expression equated to 1 .

Western blotting. Proteins were extracted from regenerating adrenals in sample buffer containing protease inhibitors, and $100 \mu \mathrm{g}$ of proteins was subjected to SDS-PAGE under reducing conditions as detailed previously $(32,33)$. Samples were resolved in a standard gel apparatus and then transferred to nitrocellulose membranes (Sigma-Aldrich Corp.). Membranes were blocked for $60 \mathrm{~min}$ at $37^{\circ} \mathrm{C}$ in Blotto A with $0.05 \%$ Tween-20, and then incubated for $60 \mathrm{~min}$ at $37^{\circ} \mathrm{C}$ with the primary goat polyclonal anti-AM antibody (Santa Cruz Biotechnology, Santa Cruz, CA), diluted 1:1,000 in Blotto A. After washing in Tris-buffered saline, membranes 
were incubated for $60 \mathrm{~min}$ at room temperature with $\mathrm{Cruz}$ Marker-compatible peroxidase-conjugated anti-goat IgG rabbit secondary antibodies (1:2,000 dilution). Negative controls were obtained by using a primary antiserum preabsorbed with $10^{-7} \mathrm{M}$ rat AM (Phoenix Pharmaceuticals, Belmont, CA). Immunoreactive bands were detected by ECL Advanced Western Blotting Detection kit (Amersham, Aylesbury, UK). Blots were scanned and quantified with a Bio-Rad Chemiluminescence Molecular Imaging system (Bio-Rad Laboratoires) and expressed as percent change from the control (taken equal to 1).

Statistical analysis. The results were expressed as the means \pm SEM ( $n=3)$, and the statistical significance of the differences among experimental groups was estimated using ANOVA followed by the Duncan's multiple range test.

\section{Results}

The PCNA index of regenerating adrenocortical cells did not undergo significant changes until 3 days after enucleation. It reached a maximum (15-fold increase) at 5 and 7 days post surgery and then declined, returning to the control level at day 28 (Fig. 1).

Conventional RT-PCR detected the expression of AM mRNA in the control regenerating adrenal cortex (time 0) (Fig. 2). Real time-PCR showed that AM gene expression was markedly increased at day 1 after surgery ( 3 -fold), attained a maximum level at days 3 and 5 ( $~ 8$-fold), and then decreased at day 7 (4.5-fold increase). At days 14 and 28, it was not significantly different from the controls (Fig. 3). In rats with intact right adrenals, AM mRNA expression in the regenerating glands displayed 6.5- and 7.5-fold increases at days 3 and 5 after surgery, respectively (Fig. 4).

Western blotting demonstrated a single 6-kDa AM protein band in the regenerating adrenals (Fig. 5). AM protein expression underwent a moderate rise at day 1 after enucleation ( 2-fold), was maximal at days 3, 5 and 7 (10- to 12-fold increases), and then decreased at days 14 and 28 , although remaining significant over the control value (Fig. 6).

\section{Discussion}

The growth of the adrenal cortex during the early stages of regeneration can be divided into two phases: an initial differentiation period (from day 0 to day 3 ) and a subsequent high proliferation period (from day 4 to day 7). From day 8, post-enucleation proliferative activity starts to decrease (7). Our present PCNA-assay findings are in complete agreement with this contention.

Coupled real time-PCR and Western blot analysis clearly showed that the early stages of adrenal regeneration were associated with up-regulation of the AM gene transcription and translation. At day 1, AM expression, as both mRNA and protein, was markedly enhanced, and the increase reached a maximum at days 3 and 5 for mRNA and days 3 and 7 for protein. Hence, up-regulation of AM gene expression may be considered one of the early events in the enucleation-induced activation of local adrenocortical stem cells, conceivably favoring both the differentiation and proliferation stages of regeneration. This contention is in keeping with the wellknown growth promoting action of AM on ZG cells (14-18), as well as with its reported stimulating effect on clonal growth of cord blood-derived mesenchymal stem cells (34).

At present, only hypotheses can be advanced on the mechanism(s) involved in the AM gene up-regulation during adrenal regeneration. Although ACTH, via cyclic-AMP, has been reported to enhance AM release from skin keratinocytes (35), the increase in its blood levels during the early stages of regeneration seems to indicate a role of minor relevance. In fact, a marked increase in AM mRNA occurred at days 3 and 5 of regeneration even in rats whose contra-lateral adrenals were preserved, and the levels of circulating ACTH were in the normal range [RIA assay - ACTH plasma concentration $(\mathrm{pg} / \mathrm{ml} \pm \mathrm{SEM}) 3$ days after surgery: sham enucleation, $70 \pm 12$; enucleation and contra-lateral adrenalectomy, $143 \pm 22$ $(\mathrm{P}<0.05)$; and enucleation without contra-lateral adrenalectomy, 75 \pm 15 ]. During the early stages of regeneration, local stem cells adherent to the capsule are conceivably exposed to relative hypoxia due to the mechanical disruption of the adrenal vascular bed, and hypoxia, via HIF, is known to up-regulate AM gene expression (36-39). Moreover, enucleation surely induces an initial inflammatory response in the regenerating adrenal tissue, and inflammatory cytokines have been shown to enhance AM gene expression through NO-dependent and NO-independent pathways $(39,40)$.

Be that as it may, the increased local production of AM may probably play a relevant role during the early stages of adrenal regeneration. Many lines of evidence demonstrate that $\mathrm{AM}$ exerts a potent in vivo and in vitro pro-angiogenic action (41-43) that may partly ensue from its direct effect on vascular endothelial cells, and partly from its stimulating effect on local VEGF production $(9,44,45)$. Hence, AM may not only increase regenerating adrenocortical cell growth, but also stimulates neovascularization to restore a normal adrenal vascular bed.

\section{References}

1. Nussdorfer GG: Cytophysiology of the adrenal cortex. Int Rev Cytol 98: 1-405, 1986.

2. Vinson GP, Whitehouse BJ and Hinson JP: The Adrenal Cortex. Prentice Hall, Englewood Cliffs (NJ), 1992.

3. Mitani F, Mukai K, Miyamoto H, Suematsu M and Ishimura Y: The undifferentiated cell zone is a stem cell zone in adult rat adrenal cortex. Biochim Biophys Acta 1619: 317-324, 2003.

4. Dallman MF: Control of adrenocortical growth in vivo. Endocr Res 10: 213-242, 1984.

5. Buckingham JC and Hodges JR: Interrelationships of pituitary and plasma corticotrophin and plasma corticosterone during adrenocortical regeneration in the rat. J Endocrinol 67: 411-417, 1975.

6. Holzwarth MA, Shinsako J and Dallman MF: Adrenal regeneration. Time course, effect of hypothalamic hemi-islands and response to unilateral adrenalectomy. Neuroendocrinology 31: 168-176, 1980.

7. Taki TM and Nickerson PA: Differentiation and proliferation of adrenocortical cells during early stages of regeneration. Lab Invest 53: 91-100, 1985.

8. Engeland WC and Levay-Young BK: Changes in the glomerulosa cell phenotype during adrenal regeneration in rats. Am J Physiol 276: R1374-R1382, 1999.

9. Albertin G, Rucinski M, Carraro G, Forneris M, Andreis PG, Malendowicz LK and Nussdorfer GG: Adrenomedullin and vascular endothelium growth factor genes are overexpressed in the regenerating rat adrenal cortex, and AM and VEGF reciprocally enhance their mRNA expression in cultured rat adrenocortical cells. Int J Mol Med 16: 431-435, 2005. 
10. Hinson JP, Kapas S and Smith DM: Adrenomedullin, a multifunctional regulatory peptide. Endocr Rev 21: 138-167, 2000.

11. Lopez J and Martinez A: Cell and molecular biology of the multifunctional peptide adrenomedullin. Int Rev Cytol 221: 1-92, 2002.

12. Poyner DR, Sexton PM, Marshal I, Smith DM, Quirion R, Born W, Muff R, Fisher JA and Foord SM: International union of pharmacology. XXXII. The mammalian calcitonin gene-related peptides, adrenomedullin, amylin and calcitonin receptors. Pharmacol Rev 54: 233-246, 2002.

13. Nussdorfer GG: Proadrenomedullin-derived peptides in the paracrine control of the hypothalamo-pituitary-adrenal axis. Int Rev Cytol 206: 249-284, 2002.

14. Andreis PG, Markowska A, Champion HC, Mazzocchi G, Malendowicz LK and Nussdorfer GG: Adrenomedullin enhances cell proliferation and deoxyribonucleic acid synthesis in rat adrenal zona glomerulosa: receptor subtype involved and signaling mechanism. Endocrinology 141: 2098-2104, 2000.

15. Semplicini A, Ceolotto G, Baritono E, Malendowicz LK, Andreis PG, Sartori M, Rossi GP and Nussdorfer GG: Adrenomedullin stimulates DNA synthesis of rat adrenal zona glomerulosa through activation of the mitogen-activated protein kinase-dependent cascade. J Hypertens 19: 599-602, 2001.

16. Andreis PG, Albertin G, Conconi MT, Carraro G, Malendowicz LK, Ziolkowska A and Nussdorfer GG: Evidence for an autocrineparacrine role of adrenomedullin in the cultured rat adrenal zona glomerulosa cells. Int J Mol Med 10: 401-405, 2002.

17. Rebuffat P, Forneris ML, Aragona F, Ziolkowska A, Malendowicz LK and Nussdorfer GG: Adrenomedullin and its receptors are expressed in the zona glomerulosa of human adrenal gland: evidence that ADM enhances proliferation and decreases apoptosis in cultured ZG cells. Int J Mol Med 9: 119-124, 2002.

18. Malendowicz LK, Conconi MT, Parnigotto PP and Nussdorfer GG: Endogenous adrenomedullin system regulates the growth of rat adrenocortical cells cultured in vitro. Regul Pept 112: 27-31, 2003.

19. Garayoa M, Bodegas E, Cuttitta F and Montuenga LM: Adrenomedullin in mammalian embryogenesis. Microsc Res Tech 57: 40-54, 2002.

20. Landberg G, Tan EM and Roos G: Flow cytometric multiparameter analysis of proliferating cell nuclear antigen/cyclin and Ji-67 antigen: a new view of the cell cycle. Exp Cell Res 187: 111-118, 1990.

21. Mazzocchi G, Rossi GP, Neri G, Malendowicz LK, Albertin G and Nussdorfer GG: 11,-Hydroxysteroid dehydrogenase expression and activity in the human adrenal cortex. FASEB J 12: 1533-1539, 1998.

22. Andreis PG, Rucinski M, Neri G, Conconi MT, Petrelli L, Parnigotto PP, Malendowicz LK and Nussdorfer GG: Neuropeptides $\mathrm{B}$ and $\mathrm{W}$ enhance the growth of human adrenocortical carcinoma-derived NCl-H295 cells by exerting MAPK p42/p44mediated proliferogenic and antiapoptotic effects. Int J Mol Med 16: 1021-1028, 2005

23. Albertin G, Carraro G and Nussdorfer GG: Human adrenomedullin gene silencing by short interfering RNAs: A preliminary study. Int J Mol Med 15: 579-583, 2005.

24. Rucinski M, Andreis PG, Ziolkowska A, Nussdorfer GG and Malendowicz LK: Differential expression and function of beacon in the rat adrenal cortex and medulla. Int J Mol Med 16: 35-40, 2005.

25. Albertin G, Carraro G, Petrelli L, Guidolin D, Neri G and Nussdorfer GG: Endothelin-1 and adrenomedullin enhance the growth of human adrenocortical carcinoma-derived SW-13 cell line by stimulating proliferation and inhibiting apoptosis. Int $\mathrm{J}$ Mol Med 15: 469-474, 2005.

26. Rucinski M, Albertin G, Spinazzi R, Ziolkowska A, Nussdorfer GG and Malendowicz LK: Cerebellin in the rat adrenal gland: gene expression and effects of CER and (des-Ser1)CER on the secretion and growth of cultured adrenocortical cells. Int J Mol Med 15: 411-415, 2005.

27. Rossi GP, Sticchi D, Giuliani L, Bernante P, Zavattero S, Pessina AC and Nussdorfer GG: Adiponectin receptor expression in the human adrenal cortex and aldosteroneproducing adenomas. Int J Mol Med 17: 975-980, 2006.
28. Albertin G, Ruggero M, Guidolin D and Nussdorfer GG: Gene silencing of human RAMP2 mediated by short-interfering RNA. Int J Mol Med 18: 531-535, 2006.

29. Carraro G, Albertin G, Aragona F, Forneris M, Casale V, Spinazzi R and Nussdorfer GG: Age-dependent decrease in the ghrelin gene expression in the human adrenal cortex: A real time PCR study. Int J Mol Med 17: 319-321, 2006.

30. Rucinski M, Ziolkowska A, Hochól A, Pucher A, Macchi C, Belloni AS, Nussdorfer GG and Malendowicz LK: Estradiol and resveratrol stimulating effect on osteocalcin, but not osteonectin and collagen- $1 \alpha$ gene expression in primary culture of rat calvarial osteoblast-like cells. Int J Mol Med 18: 565-570, 2006.

31. Ziolkowska A, Tortorella C, Nussdorfer GG, Rucinski M, Majchrzak $M$ and Malendowicz LK: Accumulation of steroidogenic acute regulatory protein mRNA and decrease in the secretory and proliferative activity of rat adrenocortical cells in the presence of proteasome inhibitors. Int J Mol Med 17: 865-868, 2006.

32. Spinazzi R, Rucinski M, Neri G, Malendowicz LK and Nussdorfer GG: Preproorexin and orexin receptors are expressed in cortisol-secreting adrenocortical adenomas and orexins stimulate in vitro cortisol secretion and growth of tumor cells. J Clin Endocrinol Metab 90: 3544-3549, 2005.

33. Ziolkowska A, Rucinski M, Tyczewska M, Belloni AS, Nowak M, Nussdorfer GG and Malendowicz LK: Down-regulation of the beacon gene expression in the regenerating rat adrenal cortex. Peptides 27: 3216-3219, 2006.

34. Del Pup L, Belloni AS, Carraro G, De Angeli S, Parnigotto PP and Nussdorfer GG: Adrenomedullin is expressed in cord blood hematopoietic cells and stimulates their clonal growth. Int $\mathrm{J}$ Mol Med 11: 157-160, 2003.

35. Kapas S, Tenchini ML and Furthing PM: Regulation of adrenomedullin secretion in cultured human skin and oral keratinocytes. J Investig Dermatol 117: 353-359, 2001.

36. Garayoa $M$, Martinez A, Lee $S$, Pio R, An WG, Neckers $L$, Trepel J, Montuenga LM, Ryan H, Johnson R, Gassmann M and Cuttitta F: Hypoxia-inducible factor-1 (HIF-1) up-regulates adrenomedullin expression in human cell lines during oxygen deprivation: a possible promotion mechanism of carcinogenesis. Mol Endocrinol 14: 848-862, 2000.

37. Hofbauer KH, Jensen BL, Kurtz A and Sandner P: Tissue hypoxygenation activates the adrenomedullin system in vivo. Am J Physiol 278: R513-R519, 2000.

38. Minamino N, Kikumoto K and Isumi Y: Regulation of adrenomedullin expression and release. Microsc Res Tech 57: 28-39, 2002.

39. Frede S, Freitag P, Otto T, Heilmaier C and Fandrey J: The proinflammatory cytokine interleukin 1 , and hypoxia cooperatively induce the expression of adrenomedullin in ovarian carcinoma cells through hypoxia inducible factor 1 activation. Cancer Res 65: 4690-4697, 2005.

40. Hofbauer KH, Schoof E, Kurtz A and Sandner P: Inflammatory cytokines stimulate adrenomedullin expression through nitric oxide-dependent and -independent pathways. Hypertension 39 161-167, 2002.

41. Nagaya N, Mori H, Mukotami S, Kangawa K and Kitamura S: Adrenomedullin: angiogenesis and gene therapy. Am J Physiol 288: R1432-R1437, 2005.

42. Ribatti D, Nico B, Spinazzi R, Vacca A and Nussdorfer GG: The role of adrenomedullin in angiogenesis. Peptides 26 : $1670-1675,2005$

43. Nikitenko LL, Fox SB, Kekoe S, Rees MCP and Bicknell R Adrenomedullin and tumor angiogenesis. Br J Cancer 94: 1-7, 2006.

44. Iimuro S, Shindo T, Moriyama N, Amaki T, Niu P, Takeda N, Iwata H, Zhang Y, Ebihara R and Nagai R: Angiogenic effects of adrenomedullin in ischemia and tumor growth. Circ Res 95: 415-423, 2004.

45. Schwarz N, Renshaw D, Kapas S and Hinson JP: Adrenomedullin increases the expression of calcitonin-like receptor and receptor activity modifying protein 2 mRNA in human microvascular endothelial cells. J Endocrinol 190: 505-514, 2006 